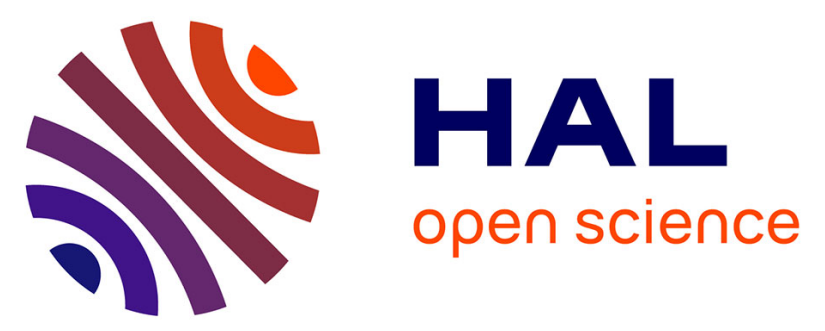

\title{
Isolation and culture of somatotrophs from the pituitary of the rainbow trout: immunological and physiological characterization
}

\author{
Claudine Weil, Elisabeth Sambroni, Muriel Bougoussa, J.L. Dacheux, \\ Pierre-Yves Le Bail, Maurice Loir
}

\section{To cite this version:}

Claudine Weil, Elisabeth Sambroni, Muriel Bougoussa, J.L. Dacheux, Pierre-Yves Le Bail, et al.. Isolation and culture of somatotrophs from the pituitary of the rainbow trout: immunological and physiological characterization. In Vitro Cellular and Developmental Biology - Animal, 1994, 30A (3), pp.162-167. 10.1007/BF02631439 . hal-02714474

\section{HAL Id: hal-02714474 \\ https://hal.inrae.fr/hal-02714474}

Submitted on 1 Jun 2020

HAL is a multi-disciplinary open access archive for the deposit and dissemination of scientific research documents, whether they are published or not. The documents may come from teaching and research institutions in France or abroad, or from public or private research centers.
L'archive ouverte pluridisciplinaire HAL, est destinée au dépôt et à la diffusion de documents scientifiques de niveau recherche, publiés ou non, émanant des établissements d'enseignement et de recherche français ou étrangers, des laboratoires publics ou privés. 


\title{
ISOLATION AND CULTURE OF SOMATOTROPHS FROM THE PITUITARY OF THE RAINBOW TROUT: IMMUNOLOGICAL AND PHYSIOLOGICAL CHARACTERIZATION
}

\author{
C. WEIL, E. SAMBRONI, M. BOUGOUSSA, F. DACHEUX, P.-Y. LE BAIL, AND M. LOIR \\ Laboratoire de Physiologie des Poissons, INRA, Campus de Beaulieu, 35042, Rennes Cedex, France; and Laboratoire de Biologie de la \\ Reproduction, Faculté des Sciences 37000 Tours and URA, INRA-CNRS 1291, 37380 Monnaie (F. D.)
}

(Received 21 April 1993; accepted 19 October 1993)

\begin{abstract}
SUMmary
The aim of the present paper was to obtain somatotroph- and gonadotroph-enriched populations from collagenase dispersed pituitaries of male rainbow trout. Inasmuch as the percentage of immunoreactive gonadotrophs and somatotrophs present in pituitaries was higher at spermiation than at the beginning of spermatogenesis, we tried such a cell separation with fish at this stage of spermatogenesis. Cells were fractionated using their differences in buoyant density with centrifugation in Percoll solutions. The use of Percoll linear gradients $(1.110$ to $1.027 \mathrm{~g} / \mathrm{ml})$ showed that somatotroph cells have a density of between 1.102 and $1.064 \mathrm{~g} / \mathrm{ml}$ whereas gonadotrophs are spread over the range of the gradient. It was thus possible, by using linear or discontinuous Percoll gradients, to obtain 95 to $67 \%$ (mean $80 \%$ ) enriched somatotropic cell fractions while no enriched gonadotropic cell fractions were collected. The fractionated cells kept their ability to be cultured and to be responsive to specific secretagogues. Somatostatine induced a 80 to $85 \%$ decrease in growth hormone release per somatotroph in the initial cell suspension as well as in the different cell fractions. On the other hand, the basal growth hormone release per cell was lower in the fractions containing cells with a density lower than 1.062 $\mathrm{g} / \mathrm{ml}$. Inversely, the gonadotrophs have a basal release per cell independent of their density, and this is also available for their responsiveness to salmon gonadotropin-releasing hormone.
\end{abstract}

Key words: somatotrophs; isolation; cell culture; rainbow trout.

\section{INTRODUCTION}

In fish as in other vertebrates the adenohypophysis consists of different cell types implicated in specific functions characterized by the production of hormones. However, a single neuropeptide, neuroamine, or steroid can affect the activity of different cell types. Moreover, it has been demonstrated that dispersed cells aggregate under certain conditions to form a tissuelike configuration (Van Der Schueren et al., 1982) and that paracrine interactions can exist between particular cell types (Denef and Andries, 1983). In consequence, to study the mechanisms by which a regulatory factor influences the secretion of a certain hormone or to study the interactions between two functions, the cell type producing this hormone or implicated in these functions should be isolated.

In fish, as in other vertebrates, there is evidence of hormonal interactions during reproduction and growth, and they may exist at different levels of the somatotropic and gonadotropic axis (review of Le Gac et al., 1993). The mechanisms involved are not yet known, and their importance might be different from one species to another. One level of interaction may be located at the hypothalamopituitary level (Fig. 1) because in cyprinids, gonadotropin-releasing hormone $(\mathrm{GnRH})$ is capable of inducing growth hormone $(\mathrm{GH})$ secretion in addition to the maturational gonadotropin $\left(\mathrm{GtH}_{2}\right)(\mathrm{Mar}-$ chant et al., 1989). Concerning GtH2 and GH secretion in salmonids, few results are available (Le Gac et al., 1993). To study the possible interaction of the two functions at the pituitary level, we attempted to purify gonadotrophs and somatotrophs of rainbow trout after having described their evolution during spermatogenesis. The technique used for fractionating these two cell types is based on their differences in buoyant density by using Percoll as the density gradient-forming agent (Pertoft et al., 1978; Hall et al., 1982). The biological activity of the cell populations obtained was studied using salmon GnRH (sGnRH) and somatostatin 14 (SRIF), known for their respective predominant positive and negative control on maturational gonadotropin (Breton et al., 1993) and growth hormone secretion (Yada and Hirano, 1992) in rainbow trout (Fig. 1).

\section{MATERIALS AND METHODS}

Animals. The determination of the number of $\mathrm{GH}$ and $\mathrm{GtH}_{2}$ cells at different stages of spermatogenesis was performed on $2^{+}$-yr-old males of a winter-spawning strain reared at the fish farm of Gournay (Oise) and weighing 0.71 kilos. All the cell purification studies were performed on 3-year old pre-spermiating or spermiating males ( $3 \mathrm{k}$ body weight) of a spring-spawning strain (Bellet Fish Farm, Angouleme). In both cases, before use, the fish were kept in the laboratory in a recirculating water unit at $13^{\circ} \mathrm{C}$ under the natural photoperiod, and fed with commercial pellets (Aqualim) at $1 \%$ of the body weight.

Preparation of dispersed pituitary cells. Dispersed cells were obtained using a collagenase procedure as previously described (Weil et al., 1986). Briefly, pituitary glands were collected in medium supplemented with antibiotic-antimycotic mixture. The whole or manually dissected pituitaries were chopped into small pieces and submitted to dispersion for $20 \mathrm{~h}$ at $12^{\circ} \mathrm{C}$ in $0.1 \%$ collagenase in RPMI buffered with $20 \mathrm{mM}$ HEPES and containing 9 


\section{HYPOTHALAMUS}

\section{PITUITARY}

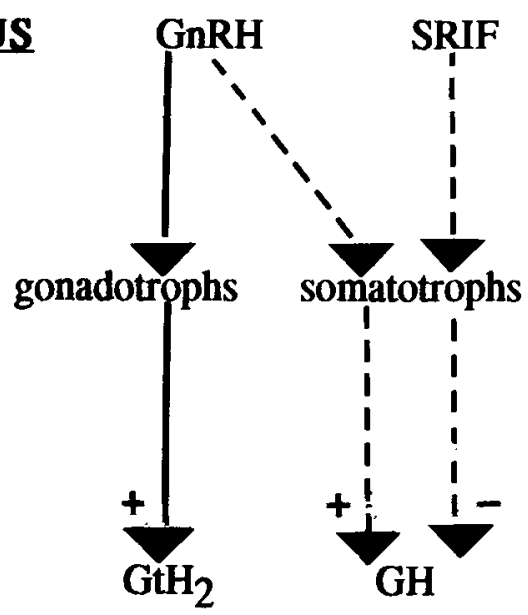

FIG. 1. Action of GnRH and SRIF on the regulation of maturational $\mathrm{GtH}_{2}$ and $\mathrm{GH}$ secretion in teleost fish.

$\mathrm{mM} \mathrm{NaHCO3}$ and $1 \%$ bovine serum albumin (BSA). The dispersed cells were filtered on a 50- $\mu \mathrm{m}$ nylon gauze previously saturated with $1 \% \mathrm{BSA}$. A cell pellet was obtained by centrifugation $(10 \mathrm{mn}$ at $200 \mathrm{~g}$ ) and two subsequent washings in culture medium supplemented with $2 \%$ of a serum substitute, ultroser SF (IBF-Sepxacor, Villeneuve la Garenne, France) and 1\% of antibiotic-antimycotic mixture. Cell counting and cell viability were determined using a Thoma hemacytometer in the presence of $0.1 \%$ trypan blue.

Gradient and cell separation. Dispersed cells were separated according to their density by centrifugation in $15 \mathrm{ml}$ Falcon conical-shaped centrifuge tubes containing Percoll solutions prepared according to the manufacturer's instructions (Pharmacia, Piscataway, NJ).

The density of the different cell types present in the preparation of the whole dispersed cells was determined using linear $(1.027$ to $1.110 \mathrm{~g} / \mathrm{ml})$ Percoll gradients. Separation of the GH cells from the other cell types was performed using Percoll cushions of $1.060 \mathrm{~g} / \mathrm{ml}$ or discontinuous ( 1.086 and $1.063 \mathrm{~g} / \mathrm{ml}$ ) Percoll gradients.

Two milliliters of cell suspension containing 6,3 , or 2 million cells was layered on top of each tube, which was centrifuged for $20 \mathrm{~min}$ at $400 \mathrm{~g}$. The collected cells were washed 3 times in RPMI supplemented with ultroser SF and antibiotics.

Identification and diameter of the cell types. The different cell types were identified by immunocytochemical staining using the peroxidase procedure (Weir et al., 1974) after attachment of the dispersed cells on poly-Llysine-treated glass slides and fixation in picric acid formaldehyde solution (PAF), as previously described (Dacheux, 1984). The staining reaction consisted of a solution of 4-chloro-naphtol. The rabbit antisera used for determining gonadotrophs 2 , somatotrophs, prolactin cells, and putative

TABLE 1

PERCENTAGE OF IMMUNOREACTIVE GONADOTROPIC $\left(\mathrm{GtH}_{2}\right)$ AND SOMATOTROPIC (GH) CELLS PRESENT IN COLLAGENASE DISPERSED PITUITARY FROM RAINBOW TROUT AT DIFFERENT STAGES OF SPERMATOGENESIS ${ }^{a}$

\begin{tabular}{|c|c|c|}
\hline \multirow{2}{*}{$\begin{array}{c}\text { Stage of } \\
\text { Spermatogenesis }\end{array}$} & \multicolumn{2}{|c|}{ Percentage of Cells } \\
\hline & $\mathrm{GtH}_{2}$ & GH \\
\hline A B spermatogonia & $11.91^{\mathrm{b}}$ & $12.42^{\mathrm{b}}$ \\
\hline Spermatocytes, spermatids & $12.01^{\mathrm{b}}$ & $12.38^{b}$ \\
\hline Spermiation & $18.27^{\mathrm{c}}$ & $19.69^{c}$ \\
\hline
\end{tabular}

a Dispersed cells were obtained from 14 males for the first two stages and 12 for the last one.

${ }^{\mathrm{b}} \mathrm{NS}=P>0.05 ;{ }^{\mathrm{c} S}=P<0.005$.
TABLE 2

PERCENTAGES OF IMMUNOREACTIVE GONADOTROPIC $\left(\mathrm{GtH}_{2}\right)$ AND SOMATOTROPIC (GH) CELLS AND NUMBER OF TOTAL CELLS RECOVERED AFTER COLLAGENASE DISPERSION OF WHOLE OR DISSECTED PITUITARIES ${ }^{a}$

\begin{tabular}{lcccc}
\hline & & \multicolumn{4}{c}{$\begin{array}{c}\text { Experiment 2 } \\
\text { Dissected Pituitaries }\end{array}$} \\
\cline { 3 - 5 } \multicolumn{1}{c}{ Cells } & $\begin{array}{c}\text { Experiment 1 } \\
\text { Whole Pituitaries }\end{array}$ & PPD & RPD & PI \\
\hline $\mathrm{GtH}_{2}, \%$ & 15.2 & 22 & 8.5 & 3.8 \\
$\mathrm{GH}, \%$ & 16.0 & 40 & 22 & 3.6 \\
Number $\times 10^{5}$ & 20.3 & 3.7 & 3.7 & 11.6 \\
\hline
\end{tabular}

${ }^{a}$ Two independent experiments ( 1 and 2$)$ were performed on two and four males, respectively.

gonadotrophs 1 and 2 plus thyreotrophs were raised against the $\beta$ subunit of chinook salmon gonadotropin 2 (Salesse et al., 1978), chinook salmon growth hormone (Le Bail et al., 1991), chinook salmon prolactin (Prunet et al., 1975), and trout gonadotropin 2 (Breton et al., 1976), respectively. They were used at a dilution of $1 / 1000$ overnight at $4^{\circ} \mathrm{C}$. The percentage of cells of a certain type was the result of duplicate analyses of 200 to 600 cells. It is expressed as the number of positive cells divided by the number of total cells counted. In the number of total cells, non-immunoreactive (NIR) cells are included; they correspond to cells secreting a hormone different from the one tested, as well as to cells having lost their secretory granules.

The determination of cell diameter was made on 30 to 100 cells identified by immunocytochemistry by using an ocular micrometer.

Culture and secretion of the cells. Dispersed cells recovered from whole pituitaries, dissected pituitaries, or Percoll fractions were resuspended in RPMI supplemented with ultroser and antibiotics. In the first case, $250 \mu \mathrm{l}$ containing $6 \times 10^{4}$ and $2.5 \times 10^{4}$ cells in the two last cases were plated into each well of 96-multiwell plates precoated with poly-L-lysine $(5 \mu \mathrm{g} /$ $\mathrm{cm}^{2}$ ). On Day 3 of culture, cells were washed twice with ultroser and antibiotic-free RPMI and incubated for $24 \mathrm{~h}$ with SRIF (generously provided by Sanofi, Labege, France) and sGnRH (Bachem, Bubendorf, Switzerland). At the end of the incubation period, plates were centrifuged respectively

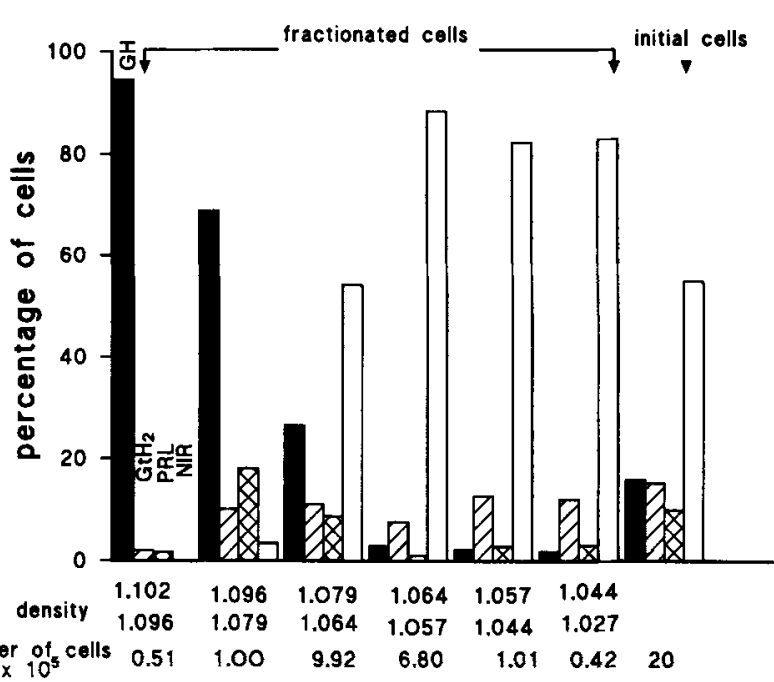

Fig. 2. Percentage of immunoreactive somatotrophs $(\mathrm{GH})$, gonadotrophs $2\left(\mathrm{GtH}_{2}\right)$, prolactin cells (PRL), NIR, and number of cells present in different fractions obtained from total pituitary cells submitted to a $10 \mathrm{ml}$ linear Percoll gradient; 1-ml fractions were collected. Donor fish were spermiating males. 


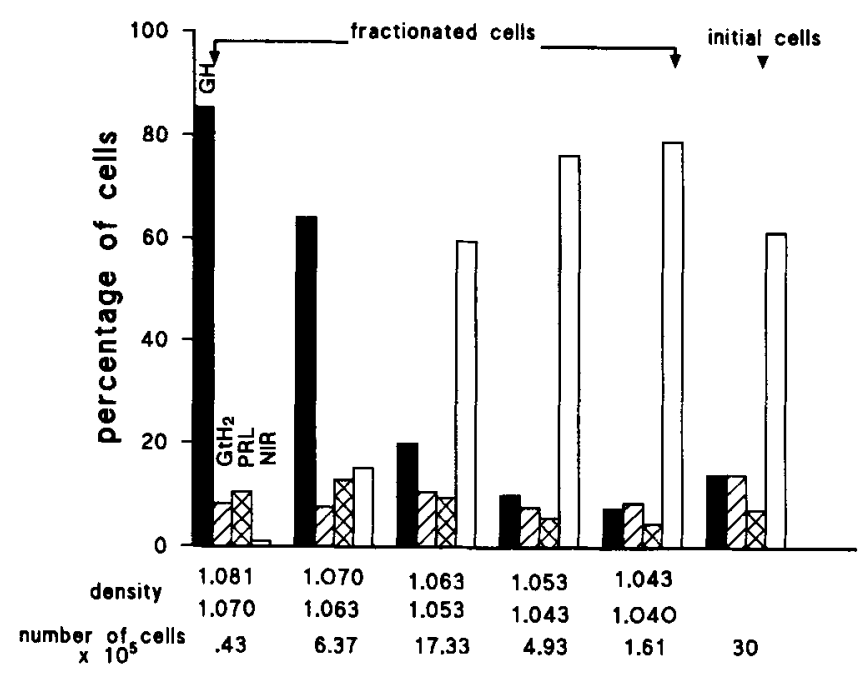

FIc. 3. Percentage of immunoreactive somatotrohs $\mathrm{GH}, \mathrm{GtH}_{2}, \mathrm{PRL}$, NIR cells, and number of cells present in different fractions obtained from male rainbow trout total adenopituitaries submitted to a $10-\mathrm{ml}$ linear Percoll gradient; 1-ml fractions were collected. Donor fish were spermiating males.

$(200 \mathrm{~g}, 10 \mathrm{~min})$. The medium was collected, then frozen, either pure or diluted, in hormone assay buffer containing $1 \%$ BSA for later GtH2 and GH determination using specific radioimmunoassays $\left(\mathrm{GtH}_{2}\right.$ : Breton et al., 1978; GH: Le Bail et al., 1991).

Statistical analysis. Means were compared by the Student's $t$ test or by a non-parametric method, the Mann-Whitney $U$ test. The differences between two variances were tested by using Fisher's test. Percentages were compared using the Chi-square test.

\section{Results}

Determination of the percentage of $\mathrm{GtH}_{2}$ and $\mathrm{GH}$ cells in collagenase dispersed pituitaries prepared from fish at different stages of spermatogenesis. During spermatogenesis, the percentages of immunoreactive $\mathrm{GtH}_{2}$ and $\mathrm{GH}$ cells followed the same evolution, with minimal values at the beginning of spermatogenesis (spermatogonia $A$ and $B$ ) and active spermatogenesis (presence of spermatocytes in all testes and spermatids in some of them), and maximal values at spermiation $(P<0.005)$. (Table 1$)$.

Enrichment of $\mathrm{GtH}_{2}$ and $\mathrm{GH}$ cells by dissection of the pituitary or purification on Percoll gradients, or both. As the number of $\mathrm{GtH}_{2}$ and $\mathrm{GH}$ cells is highest at spermiation, spermiating fish were used to determine the number of $\mathrm{GtH}_{2}$ and $\mathrm{GH}$ cells in total dispersed pituitaries or in the three dissected parts of the adenopituitary: rostral pars distalis (RPD), proximal pars distalis (PPD), and pars intermedia (PI) (Table 2). In the whole pituitary, the percentage of $\mathrm{GtH}_{2}$ and $\mathrm{GH}$ cells was 15.2 and $16 \%$, respectively. After dissection of the pituitary, $\mathrm{GtH}_{2}$ and $\mathrm{GH}$ cells were predominantly present in the dissected PPD compared to RPD and PI. As their presence is still noticed in the RPD, the whole pituitary or the whole pars distalis (PPD+RPD) were used for most of the purification on Percoll gradients. The interest in eliminating the PI was to reduce the number of cells layered on the top of the gradient by $60 \%$ (Table 2).

As shown in Figs. 2 and 3, representing typical results of Percoll linear gradients using total cells or RPD+PPD cells, respectively, the majority of $\mathrm{GH}$ cells were recovered at a specific gravity between 1.102 and $1.064 \mathrm{~g} / \mathrm{ml}$. These fractions contained 95 to $26 \%$ of $\mathrm{GH}$ cells. At lower densities, only a low percentage of $\mathrm{GH}$ cells $(<10 \%)$ is noticed. $\mathrm{GtH}_{2}$ cells are found to have very variable densities, and a purification of $\mathrm{GtH}_{2}$ cell enriched fractions was not made possible. The contamination of the $\mathrm{GH}$ cell enriched and non-enriched fractions by $\mathrm{GtH}$ cells varied between 2 and $13 \%$. Prolactin cells were also found at various densities with a percentage ranging from 2 to $18 \%$.

Using linear gradients, the total number of cells present in each fraction varies greatly ( 5 to $173 \times 10^{4}$ cells, Fig. 2 and 3 ), resulting in a variable number of $\mathrm{GH}$ cells in the enriched fractions. As the contamination by $\mathrm{GtH}_{2}$ cells is roughly equivalent in each fraction, trials were made to obtain only one enriched $\mathrm{GH}$ cell fraction to obtain sufficient numbers of purified $\mathrm{GH}$ cells. Centrifugation over Percoll (specific gravity $1.06 \mathrm{~g} / \mathrm{ml}$ ) was performed with PPD dispersed cells (Table 3). A $67.5 \% \mathrm{GH}$ cell enriched fraction (F2) was obtained at the bottom of the tube with a contamination by blood cells, $\mathrm{GtH}_{2}$ cells $(12.7 \%)$, PRL cells $(5.1 \%)$, and putative $\mathrm{GtH}_{1}$ and TSH cells $(1.2 \%)$; the top fraction $(\mathrm{Fl})$ contained $16.2 \% \mathrm{GH}$ cells, $27.8 \% \mathrm{GTH}_{2}$ cells, $5.1 \%$ PRL, and $1.2 \%$ putative $\mathrm{GtH}_{1}$ and TSH. The cell diameter of $\mathrm{GH}$ and $\mathrm{GtH}_{2}$ cells is not statistically different (Table 3). Furthermore, for each type the diameter is independent of the density of the cells because there is no difference in their diameter in the different fractions (Table 3). To get rid of blood cells, a discontinuous Percoll gradient, consisting of two layers, was used for separating RPD+PPD dispersed cells. Blood cells were at the bottom of the tube whereas a $84.6 \% \mathrm{GH}$ cell enriched fraction (F2) contaminated by $8 \%$ of $\mathrm{GtH}$ cells was at the interface between the two different gradient densities; at the top of the centrifuge tube

TABLE 3

PERCENTAGES AND DIAMETER IN MICROMETER OF IMMUNOREACTIVE GtH ${ }_{2}$ AND GH CELLS PRESENT IN COLLAGENASE DISPERSED PITUITARIES AND PROXIMAL PARS DISTALIS BEFORE OR AFTER FRACTIONATION BY CENTRIFUGATION IN A CUSHION OF PERCOLL ${ }^{\circ}$

\begin{tabular}{|c|c|c|c|c|c|c|c|c|}
\hline & \multirow{3}{*}{\multicolumn{2}{|c|}{$\begin{array}{c}\text { Total } \\
\text { Pituitary }\end{array}$}} & \multicolumn{6}{|c|}{ Proximal Pars Distalis } \\
\hline & & & \multirow{2}{*}{\multicolumn{2}{|c|}{$\begin{array}{c}\text { Before } \\
\text { Fractionation }\end{array}$}} & \multicolumn{4}{|c|}{ After Fractionation } \\
\hline & & & & & \multicolumn{2}{|r|}{ Fl } & \multicolumn{2}{|r|}{ F2 } \\
\hline & Percent & Diameter & Percent & Diameter & Percent & Diameter & Percent & Diameter \\
\hline $\begin{array}{l}\mathrm{GtH}_{2} \text { Cells } \\
\text { GH Cells }\end{array}$ & $\begin{array}{l}15.1 \\
23.5\end{array}$ & $\begin{array}{l}3.76 \pm 0.47 \\
3.54 \pm 0.35\end{array}$ & $\begin{array}{l}22.4 \\
42.2\end{array}$ & $\begin{array}{l}4.07 \pm 0.56 \\
3.42 \pm 0.35\end{array}$ & $\begin{array}{l}27.8 \\
16.2\end{array}$ & $\begin{array}{l}4.25 \pm 0.46 \\
4.06 \pm 0.67\end{array}$ & $\begin{array}{l}12.7 \\
67.5\end{array}$ & $\begin{array}{l}3.90 \pm 0.37 \\
4.14 \pm 0.55\end{array}$ \\
\hline
\end{tabular}

\footnotetext{
${ }^{a}$ Density $=1.06 \mathrm{~g} / \mathrm{ml} . \quad$ Values are $\overline{\mathrm{x}} \pm \mathrm{SD} . \quad$ F1: top fraction, F2: bottom fraction.
} 


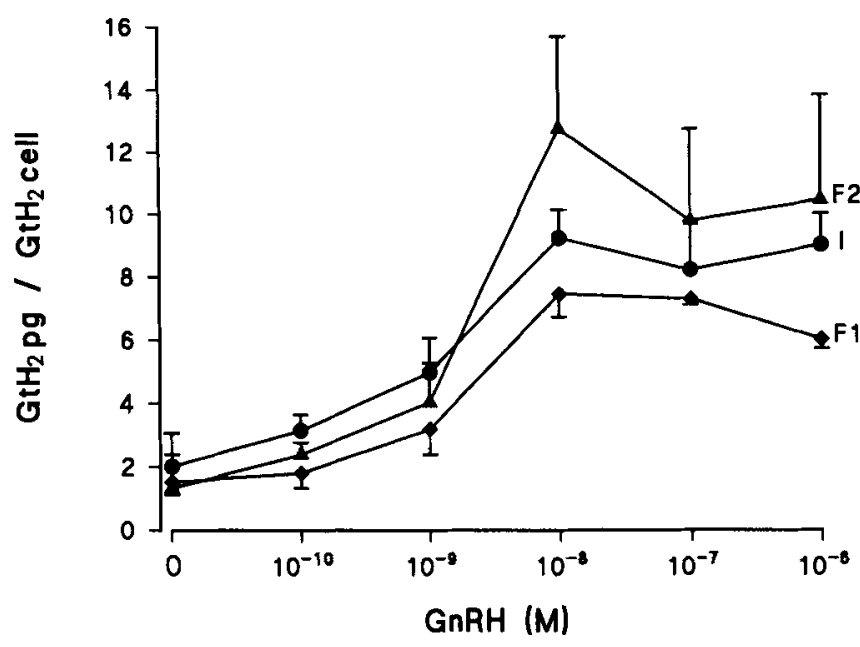

FIG. 4. $\mathrm{GtH}_{2}$ release by culture of dispersed cells obtained from the proximal pars distalis of spermiating male adenopituitaries, with or without fractionation, on a discontinuous Percoll gradient. Cells were incubated in the presence of increasing doses of sGnRH for $24 \mathrm{~h} . I=$ initial cells; $\mathrm{Fl}$ and F2 = cell fractions, same experiment as in Table 3 . Values are $\mathrm{X} \pm \mathrm{SD}$ and expressed in picograms per $\mathrm{GtH}_{2}$ cell.

a fraction (Fl) containing $\mathrm{GH}(31.6 \%), \mathrm{GtH}_{2}$ (16.5\%), PRL (19.4\%), and putative $\mathrm{GtH}_{1}$ and TSH (4.5\%) cells was present.

Cell biological activity in culture. The percentage of live cells varies from 89 to $97 \%(n=10$ experiments) and is comparable in cells submitted to collagenase dispersion with or without further purification on Percoll gradients.

All the types of dispersed cells came from total pituitary, dissected fragments, or Percoll fractionation attached to the poly-L-lysine-treated surface plastic of the wells in the same manner because they are firmly attached by Day 2 on the plastic of the wells. The typical biological activity on Day 3 of culture is shown in Figs. 4 and 5 for PPD dispersed cells, and two fractions, F1 and F2, obtained after centrifugation on a solution of Percoll (same experiment as in Table 3). The gonadotrophs show a basal release (dose 0 of $\mathrm{GnRH}$ ) and a dose-response curve to $\mathrm{GnRH}$ identical $(P>0.05)$ in the initial suspension and in the fractions (Fig. 4). However, the variability of the response is significantly higher in the F2 fraction compared to the initial cell and the Fl fraction $(P<0.01)$. Concerning the somatotrophs, the basal $\mathrm{GH}$ release per $\mathrm{GH}$ cell is identical $(P$ $>0.05)$ in the initial suspension and in the GH cell enriched fraction (F2: density $>1.06 \mathrm{~g} / \mathrm{ml}$ ) whereas in the fraction poor in somatotrophs (Fl: density $<1.06 \mathrm{~g} / \mathrm{ml}$ ) the basal $\mathrm{GH}$ release per cell is significantly lower (Fig. 5). On the other hand, in the presence of SRIF $10^{-6} M$ (Fig. 5) an inhibition in GH secretion was obtained with the same range of magnitude for each preparation of cells ( $80 \%$ for the initial cells and $85 \%$ for Fl and F2).

\section{Discussion}

The purpose of the present work was to obtain purified $\mathrm{GtH}_{2}$ and GH cells for further in vitro regulation of secretion and cell interaction studies. First, we looked for the stage of spermatogenesis at which the percentage of those cells is maximal. We found that in collagenase dispersed pituitary cells the number of $\mathrm{GtH}_{2}$ and $\mathrm{GH}$ cells increases with the advancement of spermatogenesis, maximal values being observed at spermiation. These results are in accordance with the in vivo variation of pituitary and plasma $\mathrm{GtH}_{2}$ levels (Billard et al., 1978; Weil et al., 1978) as well as with in vitro basal $\mathrm{GtH}_{2}$ release and $\mathrm{GtH}_{2}$ content of pituitary cultures (Weil and Marcuzzi, 1990) throughout the cycle. So far, no results are available on in vivo pituitary GH content during the different stages of spermatogenesis whereas plasma levels are known to increase in males by the end of the cycle (Sumpter et al., 1991; Le Gac et al., 1991, 1993).

These results led us to purify $\mathrm{GH}$ and $\mathrm{GtH}_{2}$ cells from spermiating fish. A partial enrichment by manual dissection was tried because such a technique, using rostral pars distalis fragments, resulted in a $60 \%$ enriched prolactin cell population (Le Goff et al., 1992). Using proximal pars distalis fragments, a $40 \%$ enriched $\mathrm{GH}$ cell population and a $20 \% \mathrm{GtH}_{2}$ cell population were obtained in the present work, showing the necessity to perform further purification to obtain a better enrichment in $\mathrm{GH}$ and $\mathrm{GtH}_{2}$ cells. In mammals, several methods have been developed for separating pituitary cell populations, and are based either on difference of cell size using gradients of albumin (Hymer et al., 1973) or on differences of cell density using gradients of different materials such as dextran (Ishikawa, 1969), Percoll (Pertoft et al., 1978), or in combining differences in cell size and density by using centrifugal elutriation (Hyde et al., 1982). Cell sorting after internalization of fluorescent particles or after binding of a fluorescent agonist/antagonist (Thorner et al., 1982) is also widely used. The two last techniques require special equipment. In consequence, we have chosen to use a purification based on cell density by using Percoll gradients, a method that was efficient for the purification of gonadotrophs in African catfish Clarias lazera (De Leeuw et al., 1984).

The use of Percoll linear gradients $(1.110$ to $1.027 \mathrm{~g} / \mathrm{ml}$ ) allowed us to determine the density of pituitary cells. The majority of $\mathrm{GH}$ cells have a density between 1.102 and $1.066 \mathrm{~g} / \mathrm{ml}$ whereas $\mathrm{GtH}_{2}$ cells are spread over the range of the gradient, indicating that they might represent cells at different stages of maturity. However,

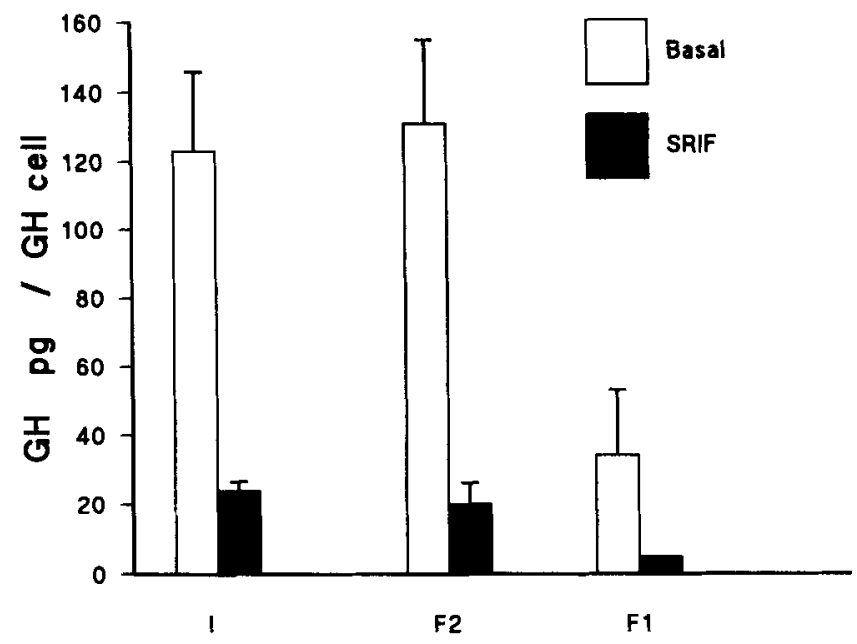

Fig. 5. Basal and SRIF $\left(10^{-6} M\right)$ induced GH release by culture of dispersed cells obtained from the proximal pars distalis of spermiating male adenopituitaries, with or without fractionation, on discontinuous Percoll gradient. Cells were incubated for $24 \mathrm{~h} . I=$ initial cells; F1 and F2 = cell fractions, same experiment as in Table 3 . Values are $\mathrm{X} \pm \mathrm{SD}$ and expressed in picograms per GH cell. 
the basal $\mathrm{GtH}_{2}$ release expressed per cell as well as the biological activity tested by $\mathrm{GtH}_{2}$ secretion in response to increasing doses of GnRH are identical for cells having a density lower or higher than $1.06 \mathrm{~g} / \mathrm{ml}$.

We were able to obtain enriched $\mathrm{GH}$ cell fractions containing 95 to $67 \%$ of $\mathrm{GH}$ cells by using continuous or discontinuous Percoll gradients or one cushion of Percoll. The use of a discontinuous gradient of Percoll or one cushion of Percoll had several advantages compared to a continuous gradient. It enabled us to obtain one enriched GH fraction containing a sufficient number of GH cells to carry out further work on the biological activity of the separated cells. In other respects, the utilization of a discontinuous gradient of Percoll made it possible to obtain a cell population that was more purified in somatotrophs because the fraction obtained was free of blood cells that are known to metabolize steroids in vitro (Schulz and Blüm, 1991). In all the cases, the GH cell enriched fractions contained 2 to $12.7 \%$ of gonadotrophs and 2 to $5 \%$ of prolactin cells, which is low. In the rat, the density of somatotrophs is in the same range (Hall et al., 1982). By using discontinuous gradients, these authors obtained two bands of somatotrophs, one containing approximately $90 \%$ somatotrophs (density: 1.075 to $1.082 \mathrm{~g} / \mathrm{cm}^{2}$ ) mixed with other cells and few lactotrophs, and the second (density 1.055 to $1.068 \mathrm{~g} / \mathrm{cm}^{2}$ ) contained about $70 \%$ somatotrophs mixed with other cells, especially lactotrophs ( $30 \%)$. These authors found that GH cells are more responsive to SRIF and to other secretagogues in the higher density band. In rainbow trout, the responsiveness to SRIF expressed in GH release per GH cell does not vary with the density of the cells. On the other hand, the basal GH secretion expressed in release per $\mathbf{G H}$ cell is superior for cells having a density higher than $1.060 \mathrm{~g} / \mathrm{ml}$ compared to cells with a density lower than $1.060 \mathrm{~g} / \mathrm{ml}$. This indicates that these two kinds of cells might either belong to two categories of cells at different stages of maturation or that during dispersion some cells have lost secretory granules without affecting the biological activity.

Our results on the density of $\mathrm{GH}$ cells, their purification, and their biological activity in culture are the first obtained in fish. The only other information available for GH cells comes from the work of De Leeuw et al. (1984) in the African catfish in which the density of acidophils, therefore including PRL and GH cells, is indicated as being between 1.083 and $1.049 \mathrm{~g} / \mathrm{ml}$. However, the identification of GH cells, as well as their biological activity, was not performed in this work.

In conclusion, a technique based on the difference of cell density seems to be appropriate for purifying $\mathrm{GH}$ cells in adult rainbow trout whereas it is not for $\mathrm{GtH}_{2}$ cells. To obtain a $\mathrm{GtH}_{2}$-enriched population from adult rainbow trout pituitaries, other methods should be tested, such as cell sorting; a technique of purification based only on the difference of cell size does not seem appropriate because we have shown that the diameter of gonadotrophs and somatotrophs are not different. The highly $\mathrm{GH}$ cell-enriched population obtained in the present work will allow us to study the action of various secretagogues on $\mathrm{GH}$ secretion as well as the effect of $\mathrm{GtH}$ supplementation on the effects observed.

\section{ACKNOWLEDGEMENTS}

We thank Drs. B. Breton and P. Prunet for supplying gonadotropin and prolactin antibodies, respectively. We are also grateful to Sanofi for supplying somatostatin. We extend our thanks to Dr. M. L. Thieulant for her helpful advice and discussion on pituitary cell enrichment. This work was supported by programme BRITTA "région Bretagne".

\section{REFERENCES}

Billard, R.; Breton, B.; Fostier, A., et al. Endocrine control of the teleost reproductive cycle and its relation to external factors. Salmonid and cyprinid models. In: Gaillard, P. J.; Boer, H. H., eds. Comparative Endocrinology. Elsevier/North Holland, Amsterdam: Biological Press; 1978:37-48.

Breton, B.; Jalabert, B.; Reinaud, P. Purification of gonadotropin from rainbow trout (Salmo gairdneri Richardson) pituitary glands. Ann. Biol. Anim. Biochem. Biophys. 16:26-36; 1976.

Breton, B.; Prunet, P.; Reinaud, P. Sexual differences in salmon gonadotropin. Ann. Biol. Anim. Biochim. Biophys. 18:754-765; 1978.

Breton, B.; Mikolajczyk, T.; Popek, W. The neuroendocrine conirol of the gonadotropin (GtH2) secretion in teleost fish in Apuaculture: Fundamental and Applied Research. Lalhou B and Viisello P, Eds. American Geophysical Union, Washington, DC, 199-215; 1993.

Dacheux, F. Subcellular localization of gonadotropic hormones in pituitary cells of the castrated pig with the use of pre- and post-embedding immunocytochemicals methods. Cell Tissue Res. 236:153-160; 1984.

De Leeuw, R.; Goos, H. J. Th.; Peute, J., et al. Isolation of gonadotrops from the pituitary of the African catfish, Clarias Lazera. Morphological and physiological characterization of the purified cells. Cell Tissue Res. 236:669-675; 1984.

Denef, C.; Andries, M. Evidence for paracrine interaction between gonadotrophs and lactotrophs in pituitary cell aggregates. Endocrinology 112:813-822; 1983.

Hall, M.; Howell, S. L.; Schulster, D., et al. A procedure for the purification of the somatotrophs isolated from rat anterior pituitary glands using Percoll density gradients. J. Endocrinol. 94:257-266; 1982.

Hyde, C. L.; Childs, G.; Wahl, L. M., et al. Preparation of gonadotrophenriched cell populations from adult rat anterior pituitary cells by centrifugal elutriation. Endocrinology 111:1421-1423; 1982.

Hymer, W. C.; Eans, W. H.; Kraicer, J., et al. Enrichment of cell types from rat adenohypophysis by sedimentation. Endocrinology 92:275$287 ; 1973$.

Ishikawa, $H$. Isolation of different types of anterior pituitary cells in rats. Endocrinol. Jpn. 16:517-529; 1969.

Le Bail, P. Y.; Sumpter, J. P.; Carragher, J. F., et al. Development and validation of a highly sensitive radioimmunoassay for chinook salmon (Oncorhynchus tshawytscha) growth hormone. Gen. Comp. Endocrinol. 83:75-85; 1991.

Le Gac, F.; Ollitrault, M.; Loir, M., et al. Binding and action of salmon growth hormone (sGH) in the mature trout testis. In: Scott, A. P.; Sumpter, J. P.; Kime, D. E., et al., eds. Proceedings of the fourth international symposium on the reproductive physiology of fish. University of East Anglia, Sheffield, UK. Norwich 1991:117-119.

Le Gac, F.; Blaise, O.; Fostier, A., et al. Growth hormone and reproduction, a review. Fish Physiol. Biochem. 11:219-232; 1993.

Le Goff, P.; Weil, C.; Valotaire, Y., et al. Effect of somatostatin on prolactin in rainbow trout (Oncorhynchus mykiss) pituitary cells in primary culture. J. Mol. Endocrinol. 9:137-146; 1992.

Marchant, T.; Chang, J. P.; Nahorniak, C. C., et al. Evidence that gonadotropin-releasing hormone also functions as a growth hormone-releasing factor in the goldfish. Endocrinology 124:2509-2518; 1989.

Pertoft, H.; Laurent, T. C.; Laas, T., et al. Density gradients prepared from colloidal silica particles coated by polyvinylpyrrolidine (Percoll). Anal. Biochem. 88:271-282; 1978.

Prunet, P.; Boeuf, G.; Houldebine, L. M. Plasma and pituitary prolactin levels in rainbow trout during adaptation to different salinities. J. Exp. Zool. 235:187-196; 1975.

Salesse, R.; Garnier, J.; Breton, B. Interaction of salmon gonadotropin subunits: spectroscopic studies. Ann. Biol. Anim. Biophys. 18:767$711 ; 1978$.

Schulz, R.; Blüm, V. Extragonadal $17 \beta$-hydroxysteroid dehydrogenase activity in rainbow trout. Gen. Comp. Endocrinol. 82:197-205; 1991.

Sumpter, J. P.; Lincoln, R. F.; Bye, V. J., et al. Plasma growth hormone levels during sexual maturation in diploid and triploid rainbow trout (Oncorhynchus mykiss). Gen. Comp. Endocrinol. 83:103-110; 1991.

Thorner, M. O.; Borges, J. L. C.; Cronin, M. J., et al. Fluorescence acti- 
vated cell sorting of functional anterior pituitary cells. Endocrinology 110:1831-1833; 1982.

Van Der Schueren, B.; Denef, C.; Cassiman, J. Ultrastructural and functional characteristics of rat pituitary cell aggregates. Endocrinology 110:513-523; 1982.

Weil, C.; Billard, R.; Breton, B., et al. Pituitary response to LH-RH at different stages of gametogenesis in the rainbow trout (Salmo gairdneri). Ann. Biol. Anim. Bioch. Biophys. 18:863-869; 1978.

Weil, C.; Hansen, P.; Hyam, D., et al. Use of pituitary cells in primary culture to study the regulation of gonadotropin hormone $(\mathrm{GtH})$ secretion in rainbow trout: setting up and validating the system as assessed by its responsiveness to mammalian and salmon gonadotro- pin releasing hormone. Gen. Comp. Endocrinol, 62:202-209; 1986.

Weil, C.; Marcuzzi, O. Cultured pituitary cell $\mathrm{GtH}$ response to $\mathrm{GnRH}$ at different stages of rainbow trout spermatogenesis and influence of steroid hromones. Gen. Comp. Endocrinol. 79:492-498; 1990.

Weir, E. E.; Pretlow, T. G.; Pitts, A., et al. A more sensitive and specific histochemical peroxidase stain for the localization of cellular antigen by the enzyme-antibody conjugate method. J. Histochem. Cytochem. 22:1135-1140; 1974.

Yada, T.; Hirano, T. Inhibition of growth hormone synthesis by somatostatin in cultured pituitary of rainbow trout. J. Comp. Physiol. B. 162:575-580; 1992. 